\title{
프로바디마사지가 근골격계 질환 중년여성의 다리정렬각 및 족저압력 균형에 미치는 영향
}

\author{
손남영 · 이중숙*
}

신라대학교

\begin{abstract}
Nam-Young Son · Joong-Sook Lee. Effects of Probody Massage on Lower Extremities Alignment Measure and Foot Plantar Pressure Balance in the Middle-Aged Women with Musculoskeletal Diseases. KINESIOLOGY, 2016, 18(1): 19-29. [PURPOSE] The purpose of this study was to investigate how 8 weeks Probody Massage program improve lower extremities alignment and plantar foot pressure in middle-aged women with musculoskeletal diseases. [METHODS] The subjects of this study were thirty middle-aged women with musculoskeletal diseases lived in B Metropolitan city, and they participated in the Probody Massage program for 8 weeks, 60 minutes a day, twice a week. Basic physical characteristics, lower extremities alignment and plantar foot pressure were measured and analyzed. [RESULTS] The Probody Massage program showed a positive change in lower extremities alignment and plantar foot pressure balance with musculoskeletal diseases in middle-aged Women. [CONCLUSIONS] This study suggested that Probody Massage improved and prevented posture unbalance of musculoskeletal diseases in middle-aged women. This program could be utilized for improvement of youth postures and foot pressure balance of musculoskeletal diseases in middle-aged women.
\end{abstract}

Key words : probody massage, musculoskeletal diseases, lower extremities alignment measure, plantar foot pressure balance 주요어 : 프로바디 마사지, 근골격계 질환, 중년여성, 다리정렬각, 족저압력 균형

\section{서론}

우리나라 여성의 평균수명이 82.5세로 연장되면서 현대사회에서 중년여성 인구가 점점 늘어나 중년여성 의 건강관리에 대한 관심이 높아지고 있다(National Statistical Office, 2013). 특히, 중년여성들의 근골격계 질환은 반복적인 작업동작과 가사노동 등으로 인한 근육조직의 손상이 누적되어 목, 어깨, 팔, 손목, 허리, 고관절 등의 부위에 악영향을 미치고, 근육 이완 및 위축에 의한 근육의 반복적인 긴장과 이완 현상에 의 해 관절가동범위( $\mathrm{ROM})$ 의 제한으로 근 골격계 질환이 발생할 가능성이 높다(Kim, 2007; Kim, 2012).

중년여성의 신체활동의 감소와 운동부족은 골반 주 변의 근력약화 및 척추안정성 저하로 이어지며 이는 자세의 불균형을 불러일으켜 척추질환 및 신체정렬 불 균형의 원인이 된다(Korean Journal of Sport Medicine, 2005; Seo, 2013). 신체정렬의 변형은 체중의 무게가
다리불균형을 초래하여 한 쪽으로 치우치게 되므로 신체 중심 기둥인 척추와 그 기둥을 지탱하는 골반에 부담을 주며 골격구조에 피로감을 쌓이게 한다(Son, 2014). 또한 골반이 바르지 않으면 척추도 한 방향으 로 기울어지게 되어 신체의 구조적 변위 및 다리불균 형을 초래하고, 더 나아가 족부의 변형과 자세 및 보 행에도 영향을 미치게 된다(Nam et al., 2003). 족부는 우리 인체 중 기립 자세에서 지면에 맞닿는 유일한 부위이며 사람에게 가장 중요한 이동수단으로서 모든 체중부하를 받는 중요한 역할을 담당한다(Saltzman et al., 1995). 그러나 인체의 움직임과 보행의 기초가 되 는 족부의 변형은 족부 질환 및 족저압력의 불균형을 초래하며(Dowling, 2001), 척추변형과 신체의 좌·우 불 균형이 나타나게 된다(Lim, 2014). 또한 중년으로 갈수 록 족부의 외형뿐만 아니라 족저면의 근육 및 지방층, 섬유성 격막 등이 변하고, 이에 따라 족부 감각과 보 행 속도 및 보폭 등이 감소하게 된다(Kernozek \&

* 교신저자: jslee@silla.ac.kr 
Lamott, 1995).

이러한 족저압력은 인체 균형과 보행상태를 측정하 고 반영할 수 있는 하나의 지표이며, 지면에 닿는 압 력을 나타낼 수 있다(Jahss, 1982; Dowling, 2001). $\operatorname{Park}(1999)$ 은 운동이 아닌 마사지로 통증을 감소시키 고 근지구력을 향상시키며, 바른 자세유지 및 신체 유 연성의 회복에 효과가 있다고 하였으나 아직까지 마 사지와 같이 다양한 방법으로 신체불균형을 개선하는 연구는 미흡한 실정이다.

최근에는 마사지가 보급화되면서 신경계는 물론 순 환계, 근육계, 골격계, 혈관계 등 신체의 전반적인 분 야 과학적인 치료마사지로 발달해오고 있다(Lim et al., 2004). Han(2009)은 모태수기법이 작업환경 및 잘못된 생활습관으로 발생한 질병 등을 개선시켜 신 체구조를 바로 잡아 줌으로써 신체의 혈액순환을 정 상으로 회복시키며, 신체정렬을 통해 신체의 밸런스를 회복하는데 효과가 있다고 보고하였다. Park(2002)은 카이로프라틱과 스포츠마사지를 천장관절환자들을 대 상으로 실시한 연구 결과에서 경추, 견갑골, 골반, 요 추 등의 주요변위를 개선시키는 것으로 보고하였다. $\operatorname{Lim}(2011)$ 은 딥티슈 마사지가 긴장성 두통 및 어깨통 증을 가진 근골격계(筋骨格系)질환 환자들을 대상으로 실시한 연구결과에서 신체의 균형개선이 나타났으며 근골격계 질환으로 인한 통증이 감소되었다고 보고하 였다. Choi(2009)는 발반사요법을 실시한 연구결과에 서 정적균형능력이 향상되는 것으로 보고하였다.

이에 중년여성을 대상으로 다양한 운동을 실시하여 신체적 특성과 신체정렬, 족저압력의 균형을 도모하는 연구들이 활발히 이루어지고 있는 반면, 마사지를 통 한 연구는 미흡한 실정이다.

마사지는 피부와 근육에 영양을 원활하게 공급하고 근수축과 이완을 증대시켜 운동능력을 향상시킨다 (Song, 1989). 중년여성을 대상으로 향기요법 마사지 (Han et al., 2003; Kim \& Park, 2006; Park, 2006), 경 락마사지(Kim, 2005), 림프마사지(Park, 2006) 등을 실 시한 결과 복부비만이 효과적으로 개선되었다. 스포츠 마사지는 혈액순환 활성화와 노폐물 제거, 체내 영양 소 공급 및 산소공급을 원활하게 할뿐 아니라 신진대 사를 활성화하여 근육 및 신경조직에 새로운 활력을 주고 운동신경의 활동도 상승시켜 근육활동을 활발하
게 한다(Lee, 2003). Lee(1988)의 연구에 의하면 마사 지 시술 시 척추를 유지할 수 있게 한다고 하였으며, 특히 프로바디마사지(Kim, 2015)는 골격계의 정렬에 효과적인 재활마사지로서, 뇌병변 장애우의 생리적 반 응, 대동작 기능 및 관절가동범위( $\mathrm{ROM})$ 에 모두 긍정 적인 영향을 미친 것으로 나타났다.

따라서 본 연구에서는 $\mathrm{B}$ 광역시에 거주하는 근골격 계 질환 중년여성에게 프로바디마사지를 실시하여 중 년여성의 다리정렬 및 족저압력 균형에 미치는 정도 를 알아봄으로서 중년여성의 신체건강 및 삶의 질 향 상에 도움이 되는 프로그램으로 활용될 수 있을 것으 로 판단되며, 수술이 아닌 마사지로써 근골격계 질환 의 문제점을 해결하고 또한 바른 자세를 만드는 방법 을 제안하여, 프로바디마사지를 효과적으로 사용할 수 있는 학문적 기초자료를 제공하는데 목적이 있다.

\section{연구방법}

\section{연구대상}

본 연구는 B광역시에 거주하고 있는 40 64세 근골 격계 질환 중년여성 30 명을 연구대상으로 하였다. 또 한 연구대상자들은 프로바디마사지 프로그램에 참여 한 경험이 전혀 없었고, 6 개월 1년 이상 근골격계 질 환으로 신체정렬각인 RFAA-angle와 RTAA-angle을 측정한 결과 다리부정렬에 이상이 있으며, 주관적 통 증지수(VAS; Visual Analogue Scale)가 5이상인 여성 으로 사전에 본 연구목적에 대하여 충분한 설명을 한 후 본 연구에 자발적으로 참여하기를 희망하고, 참여 동의서에 자발적으로 서명한 40 64세 여성 30명을 모 집단으로 선정하였으며, 연구대상자들의 신체적 특성 은 <Table 1>과 같다.

\section{측정항목 및 분석방법}

\section{1) 다리정렬각 측정}

다리정렬각 변화는 각도 측정 프로그램(free screen shot capture ver. 1.7.0)을 이용하여 <Table 2>, 
Table 1. Physical characteristics of the subjects

\begin{tabular}{ccccc}
\hline Subject & $\begin{array}{c}40 \sim 49 \text { 세 } \\
(\mathrm{N}=11)\end{array}$ & $\begin{array}{c}50 \sim 59 \text { 세 } \\
(\mathrm{N}=13)\end{array}$ & $\begin{array}{c}60 \sim 64 \text { 세 } \\
(\mathrm{N}=6)\end{array}$ & $\begin{array}{c}\mathrm{M} \pm \mathrm{SD} \\
(\mathrm{N}=30)\end{array}$ \\
\hline \hline Age & $44.08 \pm$ & $55.67 \pm$ & $64.00 \pm$ & $52.70 \pm$ \\
$(\mathrm{yrs})$ & 3.32 & 2.19 & 2.28 & 8.23 \\
\hline Height & $159.05 \pm$ & $156.18 \pm$ & $152.58 \pm$ & $156.61 \pm$ \\
$(\mathrm{cm})$ & 6.05 & 4.78 & 3.44 & 5.52 \\
\hline Weight & $58.50 \pm$ & $57.61 \pm$ & $60.60 \pm$ & $58.56 \pm$ \\
$(\mathrm{kg})$ & 8.89 & 8.70 & 13.88 & 9.65 \\
\hline BMI & $23.16 \pm$ & $23.55 \pm$ & $25.89 \pm$ & $23.86 \pm$ \\
$\left(\mathrm{kg} / \mathrm{m}^{2}\right)$ & 3.64 & 2.72 & 5.16 & 3.68 \\
\hline \multirow{2}{*}{ MVAS } & $6.00 \pm$ & $7.00 \pm$ & $6.33 \pm$ & $6.33 \pm$ \\
& 1.89 & 2.04 & 1.21 & 1.21 \\
\hline
\end{tabular}

<Figure 1>, <Figure 2>와 같이 신체정렬각인 RFAA-angle과 RTAA-angle을 측정하였다(Non-profit Corporation of TheBodyLove, 2015).

다리정렬각 RFAA-angle은 <Figure 1>과 같이 우 측 전상장골극(Anterior Superior lliac Spine, ASIS)과 무릎뼈(patella) 중앙을 잇는 직선을 긋고 전상장골극 에서 수직으로 그은 수직기준선과 만나는 수직각으로 정의하였고, RTAA-angle은 <Figure 2>와 같이 우측 무릎뼈(patella)와 발목 중앙을 잇는 직선을 긋고 무릎 빼 중심점의 수직기준선과 만나는 수직각으로 정의한 후 신체정렬 상태를 측정하였다.

Table 2. Lower Extremities Alignment Measure

\begin{tabular}{|c|c|}
\hline $\begin{array}{l}\text { Measuring } \\
\text { items }\end{array}$ & Measuring method \\
\hline $\begin{array}{l}\text { Right } \\
\text { each } \\
\text { Femoral } \\
\text { Alignment }\end{array}$ & $\begin{array}{l}\text { Draw a straight line connecting the right } \\
\text { ASIS and the patella center and Meet each } \\
\text { measure, Vertical reference line drawn } \\
\text { vertically from the ASIS }\end{array}$ \\
\hline $\begin{array}{l}\text { Left } \\
\text { each } \\
\text { Femoral } \\
\text { Alignment }\end{array}$ & $\begin{array}{l}\text { Draw a straight line connecting the left } \\
\text { ASIS and the patella center and Meet each } \\
\text { measure, Vertical reference line drawn } \\
\text { vertically from the ASIS }\end{array}$ \\
\hline $\begin{array}{l}\text { Right } \\
\text { each Tibial } \\
\text { Alignment }\end{array}$ & $\begin{array}{l}\text { Right patella and ankle draw a straight line } \\
\text { connecting the center and Each measure the } \\
\text { vertical reference line and meeting center of } \\
\text { the patella }\end{array}$ \\
\hline $\begin{array}{l}\text { Left } \\
\text { each Tibial } \\
\text { Alignment }\end{array}$ & $\begin{array}{l}\text { Left patella and ankle draw a straight line } \\
\text { connecting the center and Each measure the } \\
\text { vertical reference line and meeting center of } \\
\text { the patella }\end{array}$ \\
\hline
\end{tabular}

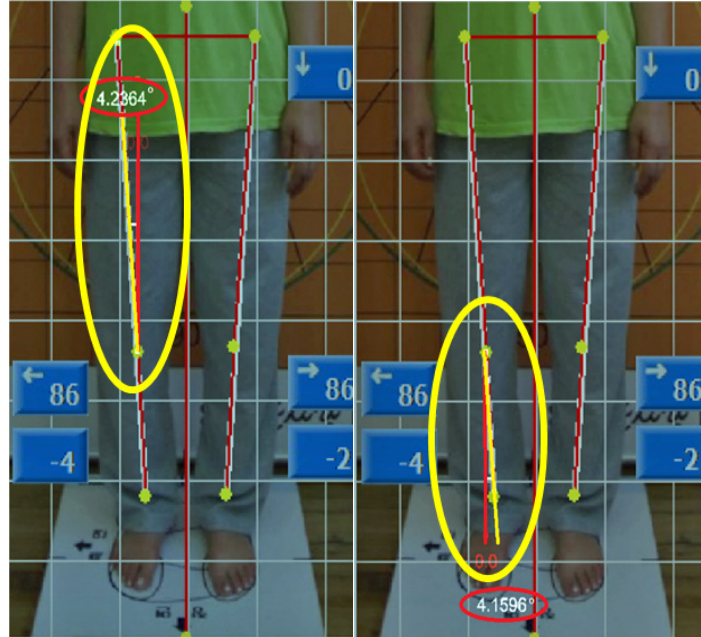

Figure 1. Right Femur Ankle Figure 2. Right Tibial Ankle Angle (RFAA-angle)

Angle (RTAA-angle)

\section{2) 족저압력 측정}

족저압력은 족저압 측정기(GHF-550, G. Hi. Well, Korea)를 이용하여 측정하였다. 수치의 기준은 50 : 50 으로 될수록 족저압력 및 발 균형이 중심에 위치 하는 것이다. 측정항목 및 측정방법은 <Table 3>, $<$ Figure $3>$, <Figure $4>$ 와 같다.

3) 프로바디마사지 프로그램의 검정 및 운영

본 연구에서 사용한 프로바디마사지는 바른체형운 동 프로그램을 응용하여 개발한 재활마사지로서(Kim, 2015), 척추만곡의 정상화와 신체정렬에 효과적인 마 사지이다.

Table 3. Foot plantar pressure

\begin{tabular}{ll}
\hline $\begin{array}{l}\text { Measuring } \\
\text { items }\end{array}$ & \multicolumn{1}{c}{ Measuring method } \\
\hline \hline $\begin{array}{l}\text { Foot } \\
\text { balance }\end{array}$ & $\begin{array}{l}\text { Standing up over the sensor and } \\
\text { the overall foot pressure measurement }\end{array}$ \\
\hline $\begin{array}{l}\text { Right foot } \\
\text { pressure }\end{array}$ & $\begin{array}{l}\text { Standing up over the sensor and } \\
\text { the overall right foot pressure } \\
\text { measurement }\end{array}$ \\
\hline $\begin{array}{l}\text { Left foot } \\
\text { pressure }\end{array}$ & $\begin{array}{l}\text { Standing up over the sensor and } \\
\text { the overall left foot pressure measurement }\end{array}$ \\
\hline
\end{tabular}




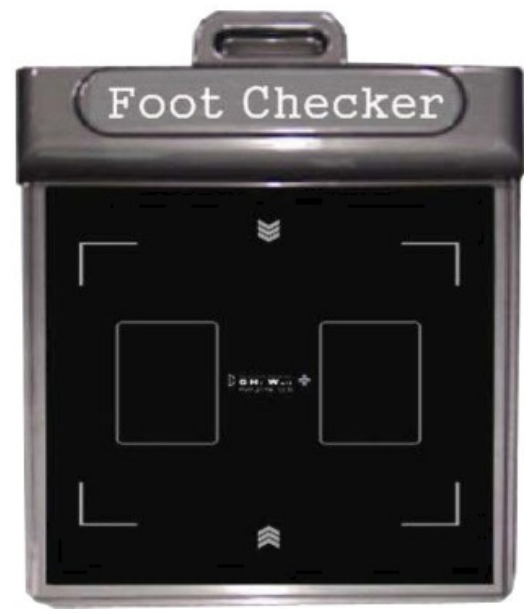

Figure 3. Foot checker

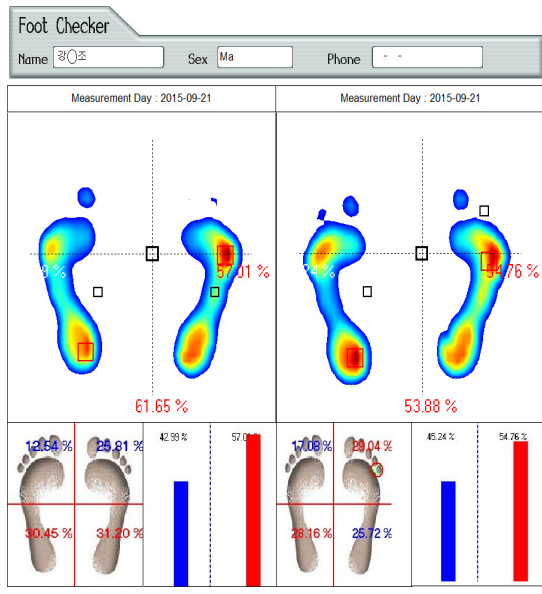

Figure 4. Plantar pressure

운동 빈도는 주 2 회, 운동시간은 1 회 60 분, 운동기 간 8주 프로그램으로 운영하였으며, 운동강도와 프로 바디마사지 프로그램 내용은 <Table $4>$ 와 같다.

프로바디마사지 프로그램을 활용한 논문은 한국운 동역학회지(Son et al., 2014), 운동학학술지(Woo et al., 2014) 등에 수차례 게재되어 이미 그 효과성을 검 정 받은 프로그램으로 수차례 수정 보완한 프로그램 이다. 또한, 프로바디마사지 프로그램은 척추 및 골격 계의 정렬을 통해 바른체형을 유지할 수 있도록 계발 된 바른체형운동 프로그램(Kim, 2013)을 응용하여 $\operatorname{Kim}(2014)$ 이 개발한 프로그램으로 본 연구에서 시행 한 프로바디마사지 프로그램은 이미 한국연구재단 등 재지에 수차례 게재되었으며, 박사학위논문 1편(Kim,
2014), 석사학위논문 3편(Kim, 2013; Oh, 2014; Son, 2014)도 발표되었다.

프로바디마사지 프로그램의 원리는 골격계의 정렬 을 개선하고, 경직된 근육을 효과적으로 풀어주며, 관

Table 4. Probody Massage Program(1 4 weeks / 5 8 weeks)

\begin{tabular}{|c|c|c|c|c|}
\hline $\begin{array}{l}\text { Subject } \\
\text { Position }\end{array}$ & Massage Contents & Massage Frequency & $\begin{array}{l}\text { Massage } \\
\text { Strength }\end{array}$ & Time \\
\hline \multicolumn{5}{|c|}{$1 \sim$ 4weeks Program / $5 \sim 8$ weeks Program } \\
\hline $\begin{array}{l}\text { Supine } \\
\text { Position }\end{array}$ & $\begin{array}{c}\text { cervical portion } \\
\text { massage } 1 \\
\text { laryngeal muscle } \\
\text { massage } \\
\text { trapezius muscle } \\
\text { massage } 1 \\
\text { hip joint massage } 1 \\
\text { quadriceps muscle } \\
\text { of thigh } \\
\text { knee joint massage } \\
\text { hip joint massage } 2 \\
\text { front crural muscle } \\
\text { massage } 1 \\
\text { front crural muscle } \\
\text { massage } 2\end{array}$ & $\begin{array}{c}\text { 3point, 3times, } \\
\text { 1set/2set } \\
\text { 2point, 3times, } \\
\text { 1set/2set } \\
\text { 3point, 3times, 1set } \\
\text { 3point, 3times, 1set } \\
\text { 4point, 3times, 1set } \\
\text { 3point, 3times, 1set } \\
\text { 3point, 3times, 1set } \\
\text { 3point, 3times, 1set } \\
\text { 2point, 3times, 1set }\end{array}$ & $\begin{array}{c}1 \sim 4 \\
\text { weeks }\end{array}$ & \\
\hline $\begin{array}{l}\text { Prone } \\
\text { Position }\end{array}$ & $\begin{array}{c}\text { back massage } 1 \\
\text { back massage } 2 \\
\text { scapula massage } \\
\text { back massage } 1 \\
\text { back massage } 2 \\
\text { hip massage } \\
\text { biceps muscle of } \\
\text { thigh } \\
\text { back crural muscle } \\
\text { massage } \\
\text { ankle massage } 1 \\
\text { ankle massage } 2 \\
\text { ankle massage } 3\end{array}$ & $\begin{array}{l}\text { 3point, 3times, 1set } \\
\text { 3point, 3times, 1set } \\
\text { 3point, 3times, 1set } \\
\text { 3point, 3times, 1set } \\
\text { 3point, 3times, 1set } \\
\text { 1point, 3times, 1set } \\
\text { 3point, 3times, 1set } \\
\text { 3point, 3times, 1set } \\
\text { 1point, 3times, 1set } \\
\text { 3point, 3times, 1set } \\
\text { 1point, 3times, 1set }\end{array}$ & $\begin{array}{l}\text { Pain } \\
\text { Stimula- } \\
\text { tion } \\
\text { Strength } \\
1 \sim 7 \\
\text { (weak } \\
\text { middle) } \\
/ \\
5 \sim 8 \\
\text { weeks } \\
\text { Pain } \\
\text { Stimula- } \\
\text { tion }\end{array}$ & $\begin{array}{c}60 \\
\min \end{array}$ \\
\hline $\begin{array}{l}\text { Supine } \\
\text { Position }\end{array}$ & $\begin{array}{l}\text { chest massage } \\
\text { cervical portion } \\
\text { massage } 2 \\
\text { cervical portion } \\
\text { massage } 1 \\
\text { laryngeal muscle } \\
\text { massage } \\
\text { arms massage }\end{array}$ & $\begin{array}{l}\text { 1point, 3times, 1set } \\
\text { 1point, 3times, } \\
\text { 1set/2set } \\
\text { 3point, 3times, } \\
\text { 1set/2set } \\
\text { 2point, 3times, 1set } \\
\text { 3point, 3times, 1set }\end{array}$ & $\begin{array}{c}\text { 7 9 } \\
\text { (middle } \\
\sim \text { strong) }\end{array}$ & \\
\hline $\begin{array}{l}\text { Sitting } \\
\text { Position }\end{array}$ & $\begin{array}{l}\text { spine muscle } 1 \\
\text { spine muscle } 2 \\
\text { shoulder joint } \\
\text { massage } \\
\text { trapezius muscle } \\
\text { massage } 2\end{array}$ & $\begin{array}{c}\text { 3point, 3times, } \\
\text { 1set/2set } \\
\text { 3point, 3times, } \\
\text { 1set/2set } \\
\text { 1point, 3times, 1set } \\
\text { 3point, 3times, 1set }\end{array}$ & & \\
\hline
\end{tabular}


절의 가동범위를 최대화하여 신체 유연성 및 움직임 을 원활하도록 돕는데 매우 효과적인 마사지이다. 프 로바디마사지는 <Table $4>$ 와 같이 총 25 가지 기법으 로 구성되어 있으며, 척추 - 관절 정렬 및 근육 마사지 를 통해 척추·관절 및 근육의 견인과 이완을 유도하 여 신체 유연성 및 움직임을 원활하게 할 뿐 아니라 신체밸런스의 안정화를 통한 심폐기능 향상 및 혈액 순환에 효과적인 마사지 기법이다.

피험자의 호흡에 맞춰 마사지를 실시하는 것이 중 요하며, 내뱉는 호흡 시 몸의 이완이 이루어지므로 모 든 마사지 동작 시 호기 호흡을 실시하게 하여 효과 성을 높인다. 또한 경추를 포함한 척추 전체의 근육을 풀어주고, 척추 정렬을 유도하여 정상만곡을 이룰 수 있도록 할 뿐 아니라 경직을 감소시킴으로써 운동기 능을 증진시키고, 골격계의 합병증을 예방하며 경직으 로 인한 통증을 없애주고 골격계를 안정화시킨다.

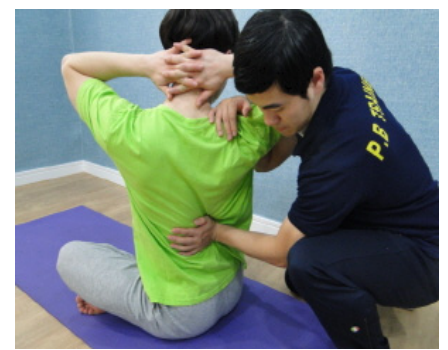

Figure 5. Spine muscle massage

프로바디마사지 실시는 Jeong(2009)의 연구방식을 적용하여 1 4주 마사지 강도는 통증자극강도 1 7(약 한 강도 중간 강도), 5 8주는 통증자극강도 7 9(중 간 강도 강한 강도)로 진행하였으며, 매회 마사지 실시 전 연구대상자의 컨디션과 주관적 통증지수를 체크하여 통증의 정도에 따라 마사지 강도를 조절하 는 방식으로 진행하였다.

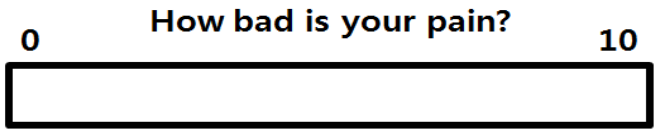

Figure 6. Massage Stimulus Intensity(Jeong, 2009)

주관적 통증지수(MVAS; Modified Visual Analogue
Scale)는 <Figure 6>과 같이 Jeong(2009)의 척도를 활 용하였으며, 이 자료는 Wang \& Kim(1995)의 동통평 가 설문지의 15 가지 문항 중 1 번 항목인 “통증은 얼 마나 심하십니까?"의 항목을 사용하여 0(전혀 아프지 않음)에서 10(매우 아픔)을 척도로 사용하였다.

\section{자료처리}

본 연구에서는 연구대상자의 일반적 특성과 자료의 분석을 위해 수집된 모든 데이터는 Windows PASW 23.0 version으로 전산처리하여 평균값과 표준편차를 산출하였고, 프로바디마사지에 따른 변인들의 프로그 램 실시 전과 후의 효과성을 검정하기 위하여 대응표 본 $t$ 검정(paired $t$-test)으로 통계처리 하였으며, 모든 측정항목의 유의수준 $(a)$ 은 .05로 설정하였다.

\section{연구결과}

\section{1. 프로바디마사지 프로그램의 실시 전·후 다리정렬각의 변화}

프로바디마사지 실시 전·후 대상자들의 다리정렬 각인 넓적다리 정렬각과 정강뼈 정렬각의 변화는 $<$ Table 5>, <Table 6>과 같다.

Table 5. Change of Femur Alignment-Angle (unit: degree)

\begin{tabular}{ccccc}
\hline Subject & $\begin{array}{c}\text { before } \\
(\mathrm{M} \pm \mathrm{SD})\end{array}$ & $\begin{array}{c}\text { after } \\
(\mathrm{M} \pm \mathrm{SD})\end{array}$ & $t$ & $p$ \\
\hline \hline Right & $-.171 \pm 2.07$ & $2.90 \pm 2.35$ & -5.949 & $.000^{* * *}$ \\
\hline Left & $.426 \pm 2.13$ & $2.02 \pm 2.05$ & -3.062 & $.005^{* *}$ \\
\hline${ }^{*} p<.05,{ }^{* *} p<.01,{ }^{* * *} p<.001$ & & &
\end{tabular}

우측 넓적다리 정렬각(RFAA; Right Femur Alignment Angle)의 변화는 <Table 5>와 같으며 우 측 전상장골극(ASIS)과 우측 무릎빼(patella) 중앙을 잇는 직선을 긋고 우측 전상장골극(ASIS)에서 수직으 로 그은 수직기준선과 만나는 각을 측정하여 분석한 
결과 통계적으로 유의미한 차이가 나타났다. 좌측 넓 적다리 정렬각(LFAA; Left Femur Alignment Angle) 의 변화는 좌측 무릎빼(patella) 중앙을 잇는 직선을 긋고 전상장골극(ASIS)에서 수직으로 그은 수직기준 선과 만나는 각을 측정하여 분석한 결과 통계적으로 유의미한 차이가 나타나지 않았다.

Table 6. Change of tibia alignment-angle (unit: degree)

\begin{tabular}{ccccc}
\hline subject & before & after & $t$ & $p$ \\
\hline \hline $\begin{array}{c}\text { Right } \\
\text { tibia-angle }\end{array}$ & $3.88 \pm 3.22$ & $2.08 \pm 2.26$ & 3.145 & $.004^{* *}$ \\
\hline $\begin{array}{c}\text { Left } \\
\text { tibia-angle }\end{array}$ & $4.73 \pm 2.67$ & $4.36 \pm 2.74$ & 0.912 & .369 \\
${ }^{*} p<.05, \quad{ }^{* *} p<.01,{ }^{* * *} p<.001$ & & &
\end{tabular}

우측 정강뼈 정렬각(RTAA; Right Tibia Alignment Angle)의 변화는 <Table 6>과 같으며 우측 무릎빼 (patella)와 발목 중앙을 잇는 직선을 긋고 우측 무릎 뼈 중심점의 수직기준선과 만나는 각을 측정하여 분 석한 결과 통계적으로 유의미한 차이가 나타났다.

좌측 정강뼈 정렬각(LTAA; Left Tibia Alignment Angle)의 변화도 좌측 무릎빼 중심점의 수직기준선과 좌측 무릎빼가 만나는 각을 측정하였으나, 통계적으로 유의미한 차이가 나타나지 않았다.

\section{2. 프로바디마사지 프로그램의 실시 전·후 족저압력 균형의 변화}

프로바디마사지 프로그램 실시 전·후 족저압력 균 형의 변화는 <Table 7>와 같다.

왼발 족저압력 변화는 <Table 7>과 같으며, 실시

Table 7. Change of Foot Plantar pressure balance (unit: \%)

\begin{tabular}{cccccc}
\hline Subject & $\begin{array}{c}\text { before } \\
(\mathrm{M} \pm \mathrm{SD})\end{array}$ & $\begin{array}{c}\text { after } \\
(\mathrm{M} \pm \mathrm{SD})\end{array}$ & $t$ & $d f$ & $p$ \\
\hline \hline Left foot & $\begin{array}{c}45.92 \pm \\
5.68\end{array}$ & $\begin{array}{c}49.67 \pm \\
1.66\end{array}$ & 3.668 & 29 & $\begin{array}{c}.0004^{* *} \\
*\end{array}$ \\
\hline Right foot & $\begin{array}{c}54.08 \pm \\
5.68\end{array}$ & $\begin{array}{c}50.33 \pm \\
1.66\end{array}$ & 3.668 & 29 & $\begin{array}{c}.0004^{* *} \\
*\end{array}$ \\
\hline difference & $\begin{array}{c}12.84 \pm \\
5.24\end{array}$ & $\begin{array}{c}2.41 \pm \\
2.33\end{array}$ & 12.339 & 29 & $\begin{array}{c}.000 \\
* * *\end{array}$ \\
\hline${ }^{*} p<.05, \quad{ }^{* *} p<.01$, & ${ }^{* * *} p<.001$ & & & &
\end{tabular}

전 $45.92 \pm 5.68 \%$ 에서 실시 후 $49.67 \pm 1.66 \%$ 로 이상적인 족저압력 균형감 비율인 $50 \%$ 에 가까워졌으며, 오른발 과 왼발의 차이가 $12.84 \pm 5.24$ 로 통계적으로 유의미한 차이가 나타났다. 오른발 족저압력 또한 왼발과 동일 하게 실시 전 $54.08 \pm 5.68 \%$ 에서 실시 후 $50.33 \pm 1.66 \%$ 로 $50 \%$ 비율에 가까워졌으며, 오른발과 왼발의 차이가 $2.41 \pm 2.33$ 으로 통계적으로 유의미한 차이가 나타났다.

\section{논의}

\section{1. 다리정렬각의 변화}

지금까지 많은 연구자들에 의해 마사지가 다리뼈 각 의 변화에 도움이 되는 것으로 보고되고 있다. 다리뼈 각 측정은 Q-angle을 통한 측정이 일반적이며, Q-angle 은 의학적 측면에서 무릎 인대의 중심선의 교차점과 무 릎빼 중앙으로부터 전상장골극(ASIS; Anterior Superior Iliac Spine)까지의 중심선이 교차해 이루는 각을 의미 하며, 일반적으로 엑스레이 상에서 측정한다(D'Amico \& Rubin, 1986). Q-angle의 정상 범주는 남자는 8 10, 여자는 12 16 정도이다(D'Amico \& Rubin, 1986). 그 러나 Q-angle에 대한 대부분의 연구에서는 정상범주를 $8 \sim 17^{\circ}$ 사이로 규정하고 있고, 정상범주에 대한 견해는 학자들마다 서로 다를 수 있으며, 의학적 측면에서 남 자는 $15^{\circ}$ 이상, 여자의 경우 $20^{\circ}$ 이상일 경우를 무릎관절 병변을 일으킬 수 있는 비정상 범주에 포함시키고 있 다(Hvid et al., 1981).

Q-angle의 선행연구와 유기적인 관계가 있는 내반 슬에 관련된 선행연구를 살펴보면, 내반슬(genu varus) 다리부정렬인 여성 8 명을 대상으로 12 주간, 주 3 회, 1 회 1 시간 20 분 정체경락 마사지 프로그램과 운 동요법 적용이 무릎간 거리 단축 즉, 다리부정렬 교정 에 미치는 영향을 연구한 결과, 중년여성의 다리부정 렬 O자 다리(bow-legged) 집단에서 신장의 긍정적인 변화와 일자다리로 변화되는 결과가 나타났으며, 무릎 간 거리가 유의하게 가까워졌으며, 좌측 고관절각도 유의하게 커진 것으로 보고되었다(Kim et al., 2010).

프로바디마사지는 치료적 마사지로서 근골격계 정 
렬 및 순환기능의 활성화에 효과적인 마사지라 할 수 있다. $\operatorname{Kim}(2015)$ 의 연구결과에 의하면 프로바디마사 지(Probody Massage)는 뇌병변장애 1급 아동들의 척 추 및 관절을 정렬시키고, 경직된 근육의 견인과 이완 을 유도하여 대동작 기능 및 관절가동범위 향상에 효 과적이라고 보고하였다.

본 연구에서는 다리의 정렬을 분석하기 위해 신체 정렬각인 RFAA-angle와 RTAA-angle을 사용하였으며, 우측 넓적다리 정렬각은 통계적으로 유의미한 차이가 나타난 반면 좌측 넓적다리 정렬각은 유의한 차이가 나타나지 않았다. 이러한 결과가 나타난 것은 사전에 우측 족저압력이 좌측 족저압력 보다 크게 나타났으나 사후에는 좌·우 족저압력의 균형상태가 통계적으로 유 의미하게 좋아진 것이 우측 넓적다리 정렬각에 긍정적 인 영향을 미친 것으로 사료된다. 이러한 결과의 원인 을 분석해보면 사전에는 신체중심선이 우측으로 편중 됨으로 인해 우측 족저압력이 더 크게 나타났으나 사 후에는 신체중심선이 중력중심선에 가까워짐에 따라 족저압력의 균형이 개선된 것으로 분석되었다.

\section{2. 프로바디마사지와 족저압력 균형의 변화}

본 연구결과에서는 8 주간의 프로바디마사지는 근골 격계 중년여성의 족저압력 균형에 긍정적인 효과가 있었다.

왼발은 실시 후 이상적인 족저압력 균형감 비율인 $50 \%$ 에 가까워졌으며, 오른발도 동일하게 실시한 후 $50 \%$ 비율에 가까워져 족저압력 균형에도 긍정적인 효과가 있었다. 이러한 결과는 마사지 및 수기요법이 발의 균형감에 영향을 미친다고 보고한 선행연구와 유사한 양상을 보이고 있다. You(2014)는 33명의 여성 노인을 대상으로 발반사요법과 정맥이완요법을 실시 한 결과 정적·동적자세의 전·후방 편차에서 족저압력 분포가 유의하게 감소하였고, 족저압력의 균형 및 심 리안정에 긍정적인 영향을 미친다고 보고하였으며, $\operatorname{Kim}(2004)$ 은 혈액투석 중인 환자를 대상으로 발반사 요법과 정맥이완요법을 실시한 결과 다리 근력이 유 의하게 증가하였다고 보고하였고, $\operatorname{Kim}(2000)$ 의 연구 에서도 직장여성을 대상으로 발반사요법과 정맥이완
요법을 실시한 결과 유의하게 증가하였다고 보고하였 으며, 무릎관절염 노인을 대상으로 한 연구에서도 다 리 혈류속도가 증가하였고, 관절통과 관절 강직이 유 의하게 감소하였다고 보고하였다(Uhm, 2003). 고령여 성의 발목에 도수치료와 스트레칭을 실시한 결과 발 목의 관절가동범위( $\mathrm{ROM})$, 균형 능력, 압력 중심 이동 면적이 통계적으로 유의미하게 감소하여 도수치료와 스트레칭이 발과 발목관절에 좋은 치료방법이라고 보 고하였다(Na et al., 2012).

이와 같이 수기요법은 근육의 혈류량 증가 및 림프 의 순환을 증가시켜 관절과 근육의 회복에 영향을 미 치며(Hasson et al., 2004), 관절가동범위(ROM)와 근육 을 증가시킨다고 보고하였다(Fileld et al., 2005). 이를 통해 수기요법이 관절의 운동성을 회복하는데 효과적 이라는 이론적인 근거를 제시하고 있다. Yook(2009)은 마사지가 발목관절의 유연성과 족저굴곡근에 미치는 효과의 연구에서 대학생 중 여성 9 명과 남성 10 명 총 19 명을 대상으로 연구를 실시한 결과, 두 가지 마사지 치료 이후에 측정된 힘에는 현저한 변화는 보이지 않 았으나 미미한 효과가 입증되어 힘의 감소 없이 발목 관절 유연성에 어느 정도의 증가가 있었다고 보고하였 다. Chol(2014)은 족저압 변화 차이를 비교하기 위하 여 20명의 대학생에게 도수치료를 실시한 결과 좌측 족저압 평균값은 실험 전 $48.9 \%$ 에서 $48.5 \%$ 로 $0.4 \%$ 감 소하여 통계적으로 유의미한 차이가 없었으며, 우측 족저압 평균값 또한 실험 전 $51.1 \%$ 에서 $51.6 \%$ 로 $0.5 \%$ 증가하였으나 통계적으로 유의미한 차이는 나타나지 않았다고 보고하였다.

그럼에도 불구하고 본 연구결과에서 프로바디마사 지가 근골격계 질환 중년여성의 족저압력 균형에 긍 정적인 결과를 나타냈는데, 이러한 결과는 족저압력의 균형이 다리정렬과 밀접한 관련이 있었다고 보고한 Son et al.(2014)의 연구결과와 유사하게 프로바디마사 지가 다리정렬 개선에 긍정적인 영향을 미쳤으며, 족 저압력의 개선에도 긍정적인 영향을 미친 것으로 분 석되었다. 


\section{결론}

본 연구는 프로바디마사지가 근골격계 질환이 있는 중년여성의 다리정렬각 및 족저압력 균형에 어떠한 영향을 미치는지 알아보고자 40 64세 여성 30명을 대 상으로 프로바디마사지를 8주간 주 2회 60분의 프로 그램을 적용하였으며, 다음과 같은 결론을 얻었다.

첫째, 프로바디마사지가 근골격계 질환이 있는 중 년여성들의 다리정렬각 변화에서 긍정적인 영향을 미 쳤음을 알 수 있었다. 향후 근골격계 질환의 개선이 필요한 다양한 연령대를 대상으로 연구가 이루어져야 할 것으로 사료되며, 이를 통해 근골격계 질환 예방 및 다리정렬각 개선은 물론 신체적 건강 증진을 도모 할 수 있을 것으로 기대된다.

둘째, 프로바디마사지가 근골격계 질환이 있는 중 년여성의 족저압력 균형의 변화에서도 왼쪽 족저압력 과 오른쪽 족저압력 모두 긍정적인 영향을 미쳤음을 알 수 있었다. 향후 프로바디마사지가 근골격계 질환 중년여성의 신체건강 및 삶의 질 향상에 도움이 되는 프로그램으로 활용될 수 있을 것으로 판단되며, 수술 이 아닌 마사지로써 근골격계 질환의 문제점을 개선 보완하고, 또한 바른자세를 만드는 방법의 제안 및 프 로바디마사지와 운동요법을 병행할 경우 더 큰 효과 성을 얻을 수 있을 것으로 기대된다.

\section{참고문헌}

Choi, M. J. (2009). The effect of using both myofascial release technique and foot reflexology on static body balance, Master's Thesis. Konkuk University graduate school, Seoul, Republic of Korea.

Chol, Y. J. (2014). Effects of Manual Therapy and Customized Functional Insole on Neck Pain, Neck Disability, Spinal Curvature and Plantar Foot Pressure Balance of Smartphone Addict, Doctoral Dissertation. Hanseo University Department of Physical Therapy Graduate
School, Cheong-Nam, Republic of Korea.

D'amico, J. C., \& Rubin, M. (1986). Influence of foot orthoses on the quadriceps angle. Journal of American Podiatry Medicine Association, 78: 337-340.

Dowling, A. M. (2001). Does obesity affect foot structure and function, foot sensation and plantar pressure distribution in children, Master's Thesis. University of Wollon- gong Department of Biomedical Science, New South Wales, Australia.

Field, T., Hernandez-Reif, M., Diego, M., Schanberg, S., \& Kuhn, C. (2005). Cortisol decreases and serotonin and dopamine increase following massage therapy. International Journal of Neuroscience, 115(10): 1397-1413.

Han, K. J. (2009). Study on the recovering way of physical imbalance through traditional korean manipulation. department of oriental medicine, Master's Thesis. Sangji University Graduate School, Gang-Won, Republic of Korea.

Han, S. H., Yang, B. S., \& Kim, H. J. (2003). Effectiveness of Aromatherapy Massage on Abdominal Obesity among Middle Aged Women. Journal of Korean Academy of Nursing, 33(6): 839-846.

Hasson D., Arnetz B., Jelveus L., \& Edelstam B. (2004). A randomized clinical trial of the treatment effects of massage compared to relaxation tape recordings on diffuse long-term pain. Psychotherapy \& Psychosomatics, 73: 17-24.

Hvid, I., Andersen, L. I., \& Schmidt, H. (1981). Chondromalacia patella. The relation to abnormal patellofemoral joint mechanics. Acta Orthopaedic Scandinavia, 52(6): 661-6.

Jahss, Melvin H. (1982). Disorders of the Foot. W. B. Saunders(Philadelphia).

Jeong, S. H. (2009). Effects of Massage As Different Intensities of Stimulation, Master's Thesis. Keimyung University Department of 
Physical Education Graduate School, Dae-Gu, Republic of Korea.

Kernozek, T. W., LaMott, E. E. (1995). Comparisons of plantar pressures between the elderly and young adults. Gait and Posture. 3(3): 143-148

Kim, E. S. (2013). Utilization of Sport Biomechanics for the Correct Posture Exercise Program (Centering in Female Middle School Students). Korean Society of Sport Biomechanics.

Kim, E. S. (2015). Effects of the Probody Massage on the Physiological Variables, Gross Motor Function and ROM in Youth with Cerebral Palsy, Case Study, Doctoral Dissertation. Silla University Department of Physical Education Graduate School, Busan, Republic of Korea.

Kim, H. J., \& Park, O. J. (2006). Effect of Aromatherapy Massage on Abdominal Fat and Body Image in Post-menopausal Women. Journal of korean academy of nursing, 37(4): 603-612.

Kim, G. S. (2012). Musculoskeletal disease status of the workers, mechanical properties and preventive care. Korean Journal of Certified Exercise Professional's Refresher Training, 37-52.

Kim, K. O. (2000). The Effects of Foot Reflex to the comfort of long time standing female Workers. Journal of the korean society of cosmetology, 7(1): 203-217.

Kim, M. S. (2005). Effects of Acupoint Massage on Middle-Aged Women, Master's Thesis. Konkuk University Biological Engineering Graduate School, Seoul, Republic of Korea.

Kim, S. J., Kim, J. C., Chang, M. J., \& Chang, W. S. (2010). Ideal Body \& Meridian Pathways Program has Conducted 12 Weeks of Middle-Aged Woman's Identity is not Varus Deformity Correction Minor Impact on Alignment. The Korean Journal of Ideal
Body \& Meridian Pathways.

Kim, Y. M. (2007). An examination on Dancer's perception of importance of body arrangement. Research of Dance Education, 18(1): $1-25$.

Kim, Y. S. (2004). Effect of Foot Reflexology on Fatigue and Lower Leg Muscle Strength among Hemodialysis Patients, Master's Thesis. Eulji University Department of Health Sciences Graduate School, Dae-Jeon, Republic of Korea.

Korean Journal of Sport Medicine (2005). Clinical orthopaedic rehabilitation : an evidence-based approach Seoul. Hanmi Medical Science.

Lee, G. S. (2003). The Effect of the Body a Part Massage after Submaximal Exercise for Blood Lactate Concentration. Korea sport research, 14(4): 1209-1216.

Lee, S. Y. (1988). Effects of massage therapy on performance-enhancing effects. Department of Physical Education, Graduate School, Myongi University.

Lim. D. H. (2011). The effect of the whole body deep-tissue massage in shoulder ache and tension headache, Master's Thesis. Chosun University Graduate School, Gwang-Ju, Republic of Korea.

Lim, E. J. (2014). The effect of lower limb strengthening exercise and gait training on body balance, foot pressure and Cobb's angle in high school female scoliosis patients with pelvic malignment syndrome. Department of Health Management Graduate School of Sport and Leisure Studies. Korea National Sport University.

Lim, J. I., No, D. S. \& Kim, J. H. (2004). Theory of health sport massage : Publishing Hong Kyoung.

Na, H. S., Her, J. G., Ko, T. S., Lee, J. S., Woo, J. H., You, Y. Y., \& Chol, Y. E. (2012). The Effects of Manual Therapy and Stretching 
on Middle Aged Female Balance and Center of Pressure. Hanyang University Journal of Aging Society, 3(1): 17-31.

Nam, J. J., Lee, Y. H. \& Lee, H. Y. (2003). Changes in population and obesity based on public health nutrition survey. Korean Journal of the study of obesity, 12: 31-59.

National Statistical Office (2013). National Statistical Office, life expectancy and health life progression. Seoul; National Statistical Office. Non-profit Corporation of TheBodyLove (2015). 2015 Teacher Training Rehabilitation Exercise Health Management. Andropos.

Oh, H. J. (2014). Effects of the upright body type exercise program on body-esteem, fear of negative evaluation and self-esteem in fermale middle school students, Master's Thesis. Silla University Department of Physical Education Graduate School, Busan, Republic of Korea.

Park, C. H. (2006). Effects of Abdominal Obesity Management Program with Aromatherapy for the Middle Aged Women, Doctoral Dissertation. Keimyung University Major of Nursing Graduate School, Dae-Gu, Republic of Korea.

Park, S. N., \& Kim, M. S. (2006). Comparative Study about the Effect of Abdomen Obesity Management Program of Middle-aged Woman - Focus on Exercise, Diet, Massage Treatment. Journal of the korean society of esthetics \& cosmeceutics, 2(2): 5-19.

Park, C. H. (2002). Effect of chiropractic and sports massage in sacroiliac joint subluxation patients, Master's Thesis. MokWon University graduate school, Dae-Jeon, Republic of Korea.

Park, J. E. (1999). A study on the effects of sports massage to waist softness, muscular strength and muscular endurance in high school students, Master's Thesis. Cheong-Ju University graduate school, Cheong-Buk, Republic of Korea.
Saltzman, C. L., Nawoczenski, D. A., \& Talbot, K. D. (1995). Measurement of the medial longitudinal archives. Archives of Physical Medicine and Rehabilitation. 76(1): 45-49.

Seo, D. H. (2013). The Effects of Sling Exercise and Lumbar Stabilization Exercise for 8 weeks on Vertebra Posture Lumbar Muscular Strength and Static Balance in Middle-aged Women, Master's Thesis. Namseoul University Dept. of Health \& Exercise Graduate School, Cheong-Nam, Republic of Korea.

Song, G, T. (1989). Sport Massage. Seoul: Publishing Kumkwang.

Son, N. Y. Lee, J. S., \& Kim, J. H. (2014). effects of the Upright Body Type Exercise Program on Postures and Foot Balance in Female High School Students, Master's Thesis. Silla University Department of Physical Education Graduate School, Busan, Republic of Korea.

Son, Y. S. (2014). The Effects of Korean Dancing-Oriented Gymnastics on Physical Fitness, Hormones and Body Alignment of Elderly Women, Doctoral Dissertation. Keimyung University Department of Physical Education Graduate School, Dae-Gu, Republic of Korea.

Uhm, D. C. (2003). Effects of foot reflexo-massage on blood velocity of lower extremities, physical status and mood of elderly patients with knee osteoarthritis, Doctoral Dissertation. Seoul National University Graduate School, Seoul, Republic of Korea.

Wang, J. M. \& Kim, D. J. (1995). Assessment of the Spinal Pain Using Visual Analogue Scale. Journal of Korean Society of Spine Surgery.

Woo, K. H., Yang, J. O., \& Lee, J. S. (2014) Effects of the upright body type exercise program on autonomic nervous system, balance, VAS in female middle school students, Master's Thesis. Silla University Department of Physical Education Graduate School, Busan, Republic 
of Korea.

Yook, J, Y. (2009). Effect of Massage on the Flexibility of Ankle Joint and Spastic Plantar Flexor. Journal of Korea Sport Research: 20(3), 69-76.

You, S. J. (2014). The Effects of Foot Reflexology and
Venous Relaxation Massage on Female Elderly Persons' Plantar Pressure, Balance, and Psychological Stability, Doctoral Dissertation. Daegu University Department of Rehabilitation Science Graduate School, Dae-Gu, Republic of Korea. 
